\title{
Peningkatan Keterampilan Menulis Kalimat Tanya Melalui Penerapan Model Pembelajaran Auditory Intellectually and Repetition (AIR) Peserta Didik Kelas II Sekolah Dasar
}

\author{
Meida Dwi Agiyati \\ Universitas Sebelas Maret \\ meidawi5@gmail.com
}

\section{Article History}

received 30/4/2021

\begin{abstract}
This study aims to improve the skills of writing interrogative sentences by applying the AIR learning model. This research is a three-cycle Classroom Action Research with 3 meetings. The research subjects were second grade students of Islamic Elementary School El-Zahwa Superior Program for the 2020/2021 academic year. This research uses observation, interviews, tests, and documentation. The validity of the data using triangulation and content validity. Analysis of the data used is an interactive model. The results of the pre-action research showed that the condition of the classical interrogative sentence writing skills was $20,83 \%$. Cycle I increased to $41,67 \%$ classically. The research was continued with the second cycle which increased to $70,83 \%$ classically, and the third cycle which increased to $87,50 \%$ classically. Based on the research results, the AIR learning model can improve the ability to write interrogative sentences for class II Umar bin Khattab for the 2020/2021 academic year.
\end{abstract}

Keywords: writing skills, AIR model, interrogative sentence

\begin{abstract}
Abstrak
Penelitian ini bertujuan untuk meningkatkan keterampilan menulis kalimat tanya dengan menerapkan model pembelajaran AIR. Penelitian ini merupakan Penelitian Tindakan Kelas tiga siklus dengan 3 kali pertemuan. Subjek penelitian ini adalah siswa kelas II SD Islam El-Zahwa Program Unggulan Tahun Pelajaran 2020/2021. Penelitian ini menggunakan observasi, wawancara, tes, dan dokumentasi. Validitas data menggunakan triangulasi dan validitas isi. Analisis data yang digunakan adalah model interaktif. Hasil penelitian pra tindakan menunjukkan bahwa kondisi keterampilan menulis kalimat tanya klasikal adalah $20,83 \%$. Siklus I meningkat menjadi $41,67 \%$ secara klasikal. Penelitian dilanjutkan dengan siklus II yang meningkat menjadi $70,83 \%$ secara klasikal, dan siklus III yang meningkat menjadi $87,50 \%$ secara klasikal. Berdasarkan hasil penelitian, model pembelajaran AIR dapat meningkatkan kemampuan menulis kalimat tanya untuk kelas II Umar bin Khattab untuk tahun ajaran 2020/2021.
\end{abstract}

Kata kunci: Keterampilan menulis, Model AIR, Kalimat tanya 


\section{PENDAHULUAN}

Pendidikan di Indonesia memiliki tujuan untuk mengembangkan potensi peserta didik agar menjadi manusia yang beriman dan bertakwa kepada Tuhan Yang Maha Esa, berakhlak mulia, sehat, berilmu, cakap, kreatif, mandiri, dan menjadi warga negara yang demokratis serta bertanggung jawab sesuai dengan UU Sisdiknas No. 20 tahun 2003. Potensi yang perlu dikembangkan peserta didik yaitu pengetahuan, sikap , dan keterampilan sesuai dengan tujuan penerapan kurikulum 2013. Menurut Susilowati (2019: 147, dalam Dimyanti dan Mudjiono, 2006). Keterampilan merupakan salah satu aspek yang harus dikuasai peserta didik dalam proses pembelajaran. Dalam pembelajaran bahasa Indonesia, peserta didik diharapkan memiliki empat keterampilan dalam berbahasa yang terdiri dari menyimak, berbicara, membaca, dan menulis. Keempat ketrampilan tesebut saling berkaitan dan menjadi satu kesatuan. Seorang anak pada dasarnya akan menyimak dari pembicaraan orang lain kemudian akan belajar berbicara. Keterampilan peserta didik dalam menulis harus diasah mulai sejak dini agar peserta didik dapat mengungkapkan atau menulis pengetahuan yang diperoleh. Menulis merupakaan salah satu keterampilan yang harus dimiliki dalam berbahasa Indonesia selain dari keterampilan menyimak, berbicara, dan membaca khususnya di Sekolah Dasar (SD). Tarigan (2005: 21, dalam Dalman 2014:4) menjelaskan bahwa menulis adalah kegiatan merangkai huruf, meyampaikan gagasan atau pikiran, melukiskan atau menurunkan lambang-lambang grafis yang menjadi suatu kalimat atau menghasilkan suatu bahasa yang dapat disampaikan kepada orang lain, melalui bahasa tulisan yang mudah di pahami.

Berdasarkan hasil wawancara, dapat disimpulkan bahwa peserta didik kesulitan dalam menulis klaimat tanya. Peserta didik kesulitan dalam memahami isi dari soal, kesulitan memahami langkah-langkah dalam penyelesaian soal. Berkaitan dengan itu, hasil kinerja guru pada pratindakan menunjukkan kategori baik dengan skor rata-rata $2,61[5]$. Sedangkan aktivitas belajar peserta didik tergolong kurang dengan skor ratarata 2. Hasil wawancara dan observasi diperkuat dengan data hasil tes pratindakan yang dilaksanakan pada tanggal 8 maret 2021. Hasil tes pratindakan menunjukkan bahwa hanya 5 peserta didik yang mendapat nilai diatas KKM (Ketuntasan Kriteria Minimal). Sedangkan 24 peserta didik mendapat nilai dibawah KKM. KKM yang ditentukan yaitu 70 . Nilai rata-rata peserta didik sebesar 60,82 dengan persentase ketuntasan $20,83 \%$. Hal tersebut membuktikan bahwa keterampilan menulis kalimat tanya kelas II Umar bin Khattab SD IPU El-Zahwa masih rendah.

Permasalahan rendahnya keterampilan menulis kalimat tanya tersebut, dapat diatasi dengan menerapkan salah satu model pembelajaran kooperatif. Penelitian mengenai keterampilan menulis kalimat sejenis dengan penelitian yang dilakukan oleh Widiastuti dan Lamai. Penelitian Widiastuti menerapkan model pembelajaran Auditory,Intellectually, and Repetition (AIR) terhadap keterampilan berbicara. Sedangkan penelitian Lamai, menerapkan metode pembelajaran latihan untuk meningkatkan kemampuan membuat kalimat kalimat tanya. Hal tersebut membuktikan bahwa model pembelajaran kooperatif dapat meningkatkan keterampilan menulis kalimat tanya. Model pembelajaran merupakan kerangka berkaitan dengan kegiatan pembelajaran. Model pembelajaran berfungsi sebagai pedoman merancang aktivitas pembelajaran. Penelitian tersebut memberikan hasil bahwa terjadi peningkatan keterampilan pemecahan masalah soal cerita melalui penerapan model pembelajaran AIR. Oleh karena itu, peneliti menerapkan model pembelajaran yang sama. Namun perbedannya terletak pada materi yang diteliti. Pada penelitian ini materi yang diteliti yaitu kalimat tanya. Penelitian Widiastuti meneliti tentang keterampilan berbicara. Hal tersebut diperkuat dengan penelitian Hasnawati, Ikma, dan A. Sari, penelitian N. Wedyawati

Beberapa penelitian tersebut menunjukkan bahwa model pembelajaran kooperatif dapat meningkatkan keterampilan menulis kalimat tanya. Model 
pembelajaran Auditory, Intellectually, and Repetition (AIR) merupakan model pembelajaran yang terdiri dari 3 tahap yaitu tahap Auditory, Intellectually, dan Repetition. Tahap auditory merupakan belajar melalui kegiatan berbicara dan mendengarkan untuk mendapatkan informasi. Tahap intellectually merupakan tahap belajar melalui kemampuan berpikir. Sedangkan tahap repetition yaitu tahap pengulangan dengan tujuan memperdalam pemahaman peserta didik. Berkaitan dengan itu, peneliti memilih mata pelajaran Bahasa Indonesia. Sehingga peserta didik diharapkan terampil dalam membuat sebuah kalimat tanya.

Berdasarkan uraian diatas maka tujuan penelitian tindakan kelas ini yaitu untuk meningkatkan keterampilan menulis kalimat tanya peserta didik kelas II Umar bin Khattab SD Islam Program Unggulan El-Zahwa melalui penerapan model pembelajaran Auditory, Intellectually, and Repetition $(A I R)$. Model pembelajaran Auditory, Intellectually, and Repetition (AIR) dapat membuat peserta didik lebih aktif dalam pembelajaran, saling berinteraksi dan bekerjasama dalam mengerjakan soal, serta memiliki pengalaman untuk menyampaikan ide atau gagasan . Hasil penelitian dapat digunakan sebagai relevansi pengembangan model pembelajaran lainnya untuk meningkatkan keterampilan pemecahan masalah.

\section{METODE}

Penelitian Tindakan Kelas (PTK) ini dilakukan dengan tiga siklus terdiri dari tiga pertemuan. Subjek penelitian adalah peserta didik kelas II Umar bin Khattab SD Islam Program Unggulan El-Zahwa tahun pelajaran 2020/2021 berjumlah 24 peserta didik. Data yang diperoleh dikumpulkan menggunakan Teknik pengumpulan data berupa observasi kinerja guru danaktivitas peserta didik, wawancara guru dan peserta didik, tes pratindakan, hasil tes siklus I, siklus II, dan siklus III, serta dokumentasi. Validitas data yang digunakan yaitu triangulasi sumber, triangulasi Teknik, dan validitas isi. Sedangkan Teknik analisis data pada penelitian ini mengacu pada model interaktif Miles dan Huberman. Prosedur penelitian tindakan kelas ini memiliki empat tahapan yaitu perencanaan tindakan, pelaksanaan, observasi, dan refleksi

\section{HASIL DAN PEMBAHASAN}

Hasil dan pembahasan penelitian ini terdiri dari empat penyajian data, yaitu: data pratindakan, data siklus I, siklus II, dan silus III. Hasil tes pratindakan menunjukkan bahwa sebagian besar peserta didik memperoleh nilai dibawah KKM. Sehingga keterampilan menulis kalimat tanya rendah. Perbandingan hasil tindakan dapat dilihat pada table dibawah ini :

Tabel 1. Perbandingan Nilai Kinerja Guru pada Przatindakan, Siklus 1, Siklus 2, dan Siklus 3

\begin{tabular}{lccc}
\hline No. & Keterangan & Rata & Kategori \\
\hline 1. & Pratindakan & 2,5 & Baik \\
2. & Siklus I & 2,61 & Baik \\
3. & Siklus II & 2,9 & Baik \\
4. & Siklus III & 3,36 & Sangat Baik
\end{tabular}

Perbandingan nilai kinerja guru pada pratindakan, siklus I, siklus II, dan siklus III dapat disajikan dalam bentuk grafik pada gmabar berikut ini : 


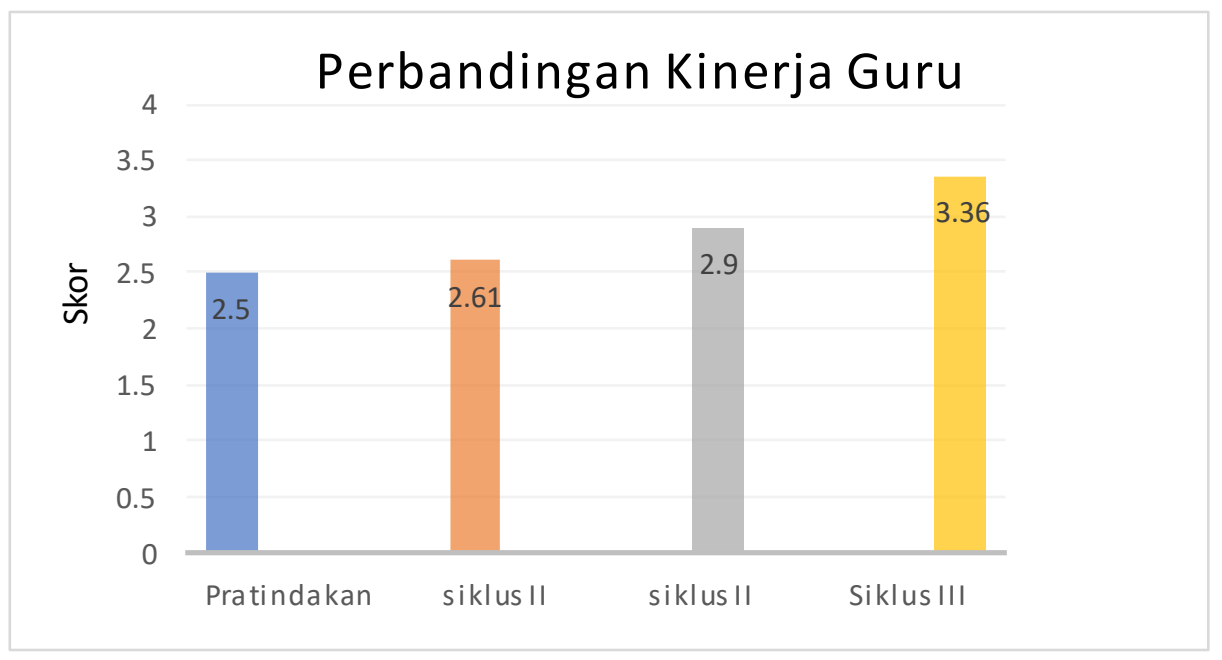

Gambar 1. Perbandingan Kinerja Guru

Berdasarkan tabel dan gambar menunjukkan bahwa rata kinerja guru pratindakan tergolong rendah dengan rata 2,5 kemudian menignkat pada siklus 1 sebesar 2,61 dan tergolong baik. Serta meningkat pada siklus 2 sebesar 2,9 dan tergolong baik. Kemudian pada siklus 3 meningkat sebesar 3,36 dan tergolong sangat baik.

Tabel 2. Perbandingan Nilai Aktivitas Peserta Didik Pratindakan, Siklus I, Siklus

\begin{tabular}{lccc}
\hline No. & Keterangan & Rata & Kategori \\
\hline 1. & Pratindakan & 2 & Kurang \\
2. & Siklus I & 2,61 & Baik \\
3. & Siklus II & 3,0 & Baik \\
4. & Siklus III & 3,3 & Sangat Baik \\
\hline
\end{tabular}

Perbandingan nilai aktivitas peserta didik pada Pratindakan, siklus I, siklus II , dan siklus III dapat disajikan dalam bentuk grafik pada gambar berikut ini:

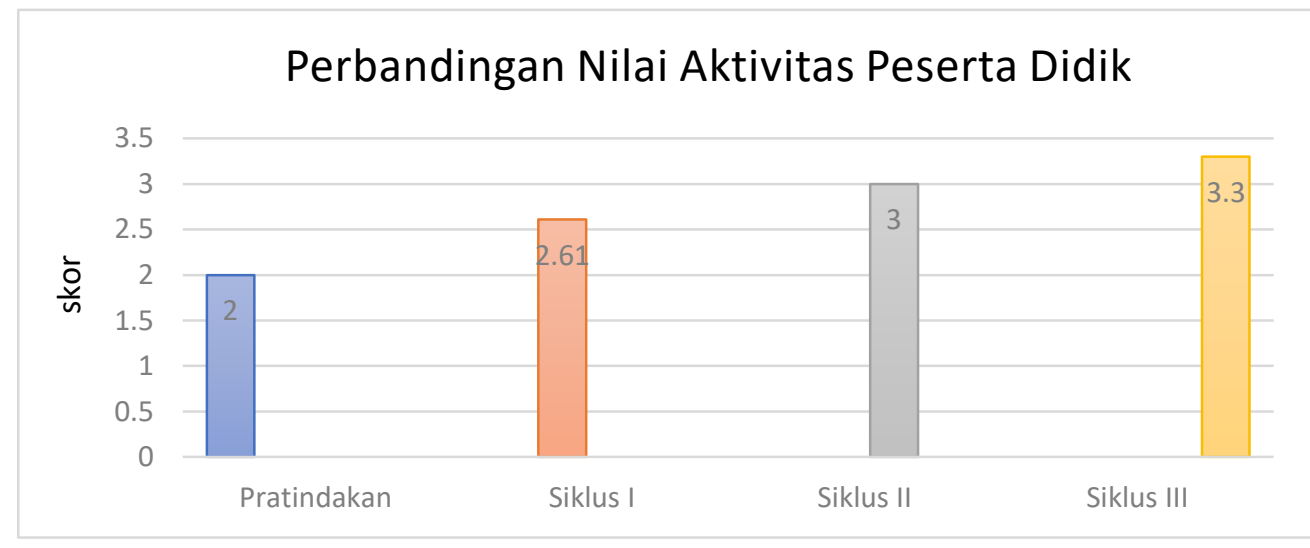

Gambar 2. Perbandingan Nilai Aktivitas Peserta didik Pada Pratindakan, Siklus I, Siklus II, dan Siklus III. 
Volume 9 Nomor 1 Tahun 2021

Hasil keterampilan mengalami peningkatan setiap siklusnya. Peningkatan hasil keterampilan dapat dilihat pada tabel sebagai berikut:

Tabel 3. Perbandingan nilai keterampilan pada Pratindakan, siklus I, siklus II, dan Siklus III.

\begin{tabular}{lccccc}
\hline No. & Keterangan & Pratindakan & Siklus I & Siklus II & Siklus III \\
\hline 1. & Nilai Tertinggi & 88 & 92 & 94 & 100 \\
2. & Nilai Terendah & 44 & 54 & 58 & 67 \\
3. & Nilai Rata & 60,82 & 70,72 & 76,04 & 86,81 \\
4. & Ketuntasan Klasika (\%) & $20,83 \%$ & $41,67 \%$ & $70,83 \%$ & $87,50 \%$ \\
\hline
\end{tabular}

Perbandingan nilai keterampilan pada Pratindakan, siklus I, siklus II, dan siklus III dapat disajikan dalam bentuk grafik pada gambar berikut ini :

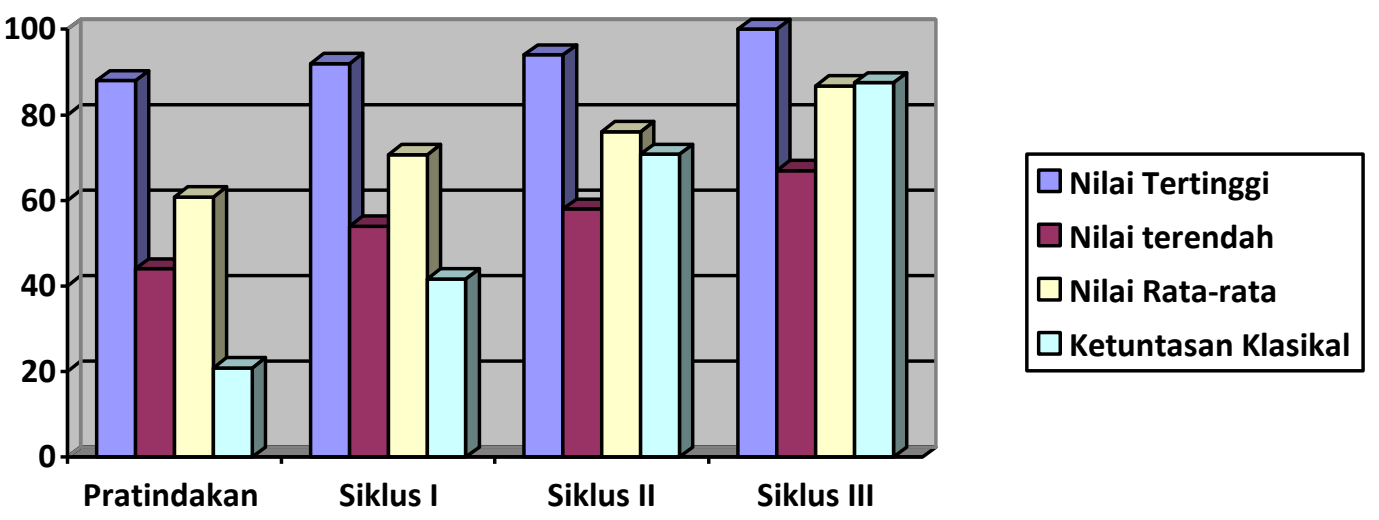

Gambar 3. Perbandingan nilai keterampilan pada Pratindakan, siklus I, siklus II , dan siklus III.

Berdasarkan tabel dan gambar 3 tersebut, Rata nilai, nilai tertinggi, nilai terendah, dan ketuntasan klasikal keterampilan melalui penerapan model AIR selalu meningkat mulai dari pratindakan, siklus I, siklus II, dan siklus III. Nilai rata pratindakan 60,82 meningkat pada siklus I menjadi 70,72 dan meningkat lagi pada siklus II menjadi 76,04 , kemudian meningkat pada siklus III menjadi 86,81. Nilai tertinggi pratindakan 88 meningkat menjadi 92 pada siklus I, dan 94 pada siklus II, serta 100 pada siklus III. Nilai terendah pratindakan 44 menjadi 54 pada siklus I dan 58 pada siklus II, dan pada siklus III menjadi 67. Selain itu, ketuntasan klasikal pratindakan, ketuntasan klasikal pratindakan $20,83 \%$ meningkat menjadi $41,67 \%$ pada siklus I dan meningkat menjadi $70,83 \%$ pada siklus II, dan pada siklus III meningkat menjadi $87,50 \%$. Ketuntasan klasikal dan rata siklus III sudah mencapai indikator ketercapaian yaitu $87,50 \%$ dengan rata 86,81 . Hal tersebut membuktikan bahwa keterampilan menulis kalimat tanya meningkat melalui penerapan model AIR.

\section{SIMPULAN}

Berdasarkan penelitian dapat ditarik kesimpulan, model pembelajaran AIR dapat meningkatkan keterampilan menulis kalimat tanya pada peserta didik kelas II Umar bin Khattab SD Islam Program Unggulan El-Zahwa. Hal tersebut terbukti 
dengan adanya peningkatan nilai kinerja guru, nilai aktivitas peserta didik dan nilai keterampilan pemecahan masalah bangun datar dari pratindakan, siklus I, siklus II, dan siklus III. Berhubungan dengan persentase ketuntasan klasikal 20,83\% meningkat menjadi $41,67 \%$ pada siklus I dan meningkat lagi pada siklus II sebesar 70,83\%, pada siklus III meningkat menjadi $87,50 \%$. Setiap aspek keterampilan pemecahan masalah pada siklus III sudah mencapai indikator yang ditentukan, Selain itu, Meningkatnya keterampilan pemecahan masalah dipengaruhi adanya peningkatan nilai kinerja guru dan nilai aktivitas peserta didik. Nilai kerja guru pada siklus I 2,61 dalam kategori baik, dan meningkat pada siklus II sebesar 2,9 kategori baik, kemudian mengalami peningkatan pada siklus III sebesar 3,36. Sedangkan nilai aktivitas peserta didik pada pratindakan meningkat dari kategori kurang baik menjadi baik pada siklus I, dan meningkat lagi menjadi 3,0 dengan kategori baik pada siklus II, dan pada siklus III meningkat sebesar 3,3 dengan kategori sangat baik..

\section{DAFTAR PUSTAKA}

Anas, Salahudin. (2015). Penelitian Tindakan Kelas. Bandung: Pustaka Setia

Ekawati, M. (2018). Peningkatan Keterampilan Pemecahan Masalah Soal Cerita Bangun Datar Melalui Penerapan Model Pembelajaran Auditory, Intellectually, Repetition (AIR).PGSD:UNS

Huda, M. (2013). Model-model Pengajaran dan Pembelajaran. (S. Z. Q. Dan A. Fawaid, Ed.) (1st ed). Yogyakarta: Pustaka Pelajar.

Lamai, S, Syamsuddin, dkk. (2014). Upaya Kemampuan Membuat Kalimat Tanya melalui Metode Latihan pada Siswa Kelas III SDN Bakalan. Jurnal Kreatif Online Vol. 6 No. 4

Moleong, Lexy J. (2012). Metode Penelitian Kualitatif Edisi Revisi.Bandung:Remaja Rosdakarya

Mulyasa, E. (2011). Praktik Penelitian Tindakan Kelas: Menciptakan Perbaikan Berkesinambungan. Bandung: Remaja Rosdakarya.

Ridia, Noni S, dan Ekasatya A.A. (2019). Perbandingan Kemampuan Pemahaman Matematis Siswa melalui Auditory Intellectually Repetition dan Student Teams Achievement Division. Jurnal Pendidikan Matematika Vol. 8 No. 3

Sari, tri Y. (2018). Upaya Peningkatan Kemampuan Menulis Siswa Pada Mata Pelajaran Bahasa Indonesia Dengan Menggunakan Gambar Seri Bagi Siswa Kelas III SDN 3 Tempuran Lampung Tengah Tahun Pelajaran 2017/2018. PGMI : IAIN Metro.

Simang, R, Efendi, dkk. (2014). Menigkatkan Kemampuan Siswa Menggunakan Kalimat Tanya Melalui Metode Latihan pada Siswa Kelas IV SD Inpres 2 Langleso. Jurnal Kreatif Online Vo. 7 No. 1

Susilowati, E, Lise C, dkk. (2019). Peningkatan Keterampilan Membuat Kalimat Tanya Berdasarkan Gambar Melalui Penerapan Model Kooperatif Tipe Scramble Pada Siswa Kelas II SDN Sumbersari 1. Jurnal Basicedu Vo. 3 No. 1 Tahun 2019

Undang-Undang Republik Indonesia Nomor 20 Tahun 2003 Tentang Sistem Pendidikan Indonesia.

Widiastuti, Y, Yuniasih dkk. (2014) . Pengaruh Model Auditory Intellectually and Repetition Berbantuan Tape Recorder Terhadap Keterampilan Berbicara. Jurnal Mimbar PGSD Vol. 2 No. 1 Tahun 2014.

Kim, C., Mirusmonov, M., Lee, I. (2010). An Empirical Examination of Factors Influencing the Intention to Use Mobile Payment. Computers in Human Behavior, 26 (1), 310-322.

Johnson, B. \& Christensen, Larry. (2012). Educational Research: Quantitative, Qualitative, and Mixed Approaches $\left(4^{\text {th }}\right.$ ed). London: SAGE Publication Ltd.

Hakim, C.. (2016, Juni 16). Kode Morse THR. Kompas Online. Diakses dari http://www.kompas.com 
Volume 9 Nomor 1 Tahun 2021

Young, R.F. (2007). Crossing Boundaries in Urban Ecology (Doctoral Dissertation). Tersedia dari Proquest Dissertation \& Theses Database. 